\title{
A MOSTRA CULTURAL "GENTE E CORPO": DIVULGANDO A CIÊNCIA E DESENVOLVENDO A ALFABETIZAÇÃO CIENTÍFICA NA EDUCAÇÃO BÁSICA
}

\author{
Rodolfo Moura Pereira, Carlos Roberto Pires Campos \\ Instituto Federal do Espírito Santo \\ Vitória, Espírito Santo \\ E-mail: rodolfoefi@yahoo.com.br,carlosr@ifes.edu.br
}

\section{Marcelo Borges Rocha}

Centro Federal de Educação Tecnológica Celso Suckow da Fonseca

Rio de Janeiro, Rio de Janeiro

E-mail: rodolfoefi@yahoo.com.br,carlosr@ifes.edu.br

Resumo: As feiras escolares configuram-se como eventos de divulgação cientifica e objetivam difundir o conhecimento científico no ambiente escolar, para a comunidade em geral. As teorias relacionadas à produção e à divulgação da ciência nos permitem construir a ideia de uma Mostra Cultural que destaca não só conteúdos das ciências como também de outras áreas. Este artigo busca destacar a relevância social da Mostra Cultural, como evento de divulgação científica, destacando seu potencial na promoção da alfabetização científica dos atores escolares. Para tanto, traz para o centro do palco alunos e professores, tornando-os protagonistas do processo de divulgação do conhecimento científico. Como resultado foi possível apontar avanços significativos na alfabetização científica de alunos, com relação ao conhecimento sobre seu corpo e destacar junto à equipe de professores a relevância de eventos de divulgação científica com vistas à socialização da ciência.

Palavras-chave: mostra cultural. práticas pedagógicas. divulgação científica. ensino de ciências.

\section{CULTURAL EXPOSITION "PEOPLE AND BODY": COMMUNICATING SCIENCE AND DEVELOPING SCIENTIFIC LITERACY IN BASIC EDUCATION}

Abstract: School fairs can be recognized as events for scientific dissemination in the school environment. Theories related to the production and dissemination of science allow us to build the idea of a cultural fair which highlights not only science contents as well as other areas. This article develops an approach on the social relevance of cultural fairs, such as events for popularization of science, highlighting its potential in promoting scientific literacy of school actors. Therefore, it brings to the center stage students and teachers, making them protagonists of the dissemination of scientific knowledge process. As a result it was possible to point out to significant advances in scientific literacy of students with regard to knowledge about their body and to point out with the teaching staff the importance of scientific dissemination events aimed at the socialization of science.

Keywords: cultural fair. pedagogical practices. science sociology. teaching sciences..

Recebido em 17/10/2015. Publicado em 30/03/2016. 


\section{INTRODUÇÃO}

Podemos compreender a divulgação científica a partir de seu propósito de levar o conhecimento científico ao público em geral, utilizando-se diversos canais, em múltiplos suportes, tais como revistas impressas, revistas eletrônicas, programas de rádio, televisão, internet, feiras, mostras culturais, espaços educativos não formais, congressos. Mecanismos eficientes de divulgação científica podem favorecer ao público uma compreensão mínima sobre ciência, para que ele consiga participar dos debates políticos e se posicione acerca de temas relacionados à ciência e à tecnologia que afetam diretamente sua vida. Segundo Chassot (2003), a ciência é uma forma de linguagem que tenta explicar os fenômenos que ocorrem na natureza e, para compreendermos esses fenômenos, é necessário dominar essa linguagem, o que significa entender o mundo em que vivemos, com que nos relacionamos, compreendendo-o por meio das explicações científicas.

Para que os conhecimentos científicos cheguem ao público em geral, a divulgação científica é de suma importância e, para tanto, serve bem a mostra cultural, a qual revela tanto uma faceta de ação cultural, dialogando com Teixeira Coelho (2001, p. 33) para quem a "ação cultural tem sua fonte, seu campo e seus instrumentos na produção simbólica de um grupo", quanto uma faceta de divulgação científica. Como agentes da ação cultural participam estudantes e professores, que se organizam para realizar eventos, os quais servem de espaço para a divulgação de seus trabalhos e apresentações, e o público, que tem a chance de participar destes eventos e entrar em contato com a cultura científica. Este artigo debruça-se sobre a seguinte questão: em que medida a Mostra Cultural 'Gente e corpo' realizada na Escola Germano André Lube, localizada no Bairro das Laranjeiras em Jacaraípe, no município de Serra (ES), potencializa a socialização de conhecimentos não contemplados no currículo escolar, de modo a fortalecer práticas sociais, proporcionando resultados na integração do campo cultural na escola, valorizando o trabalho colaborativo? Este artigo tem como objetivo apresentar uma atividade pedagógica no campo da divulgação científica, uma Mostra Cultural, destacando seu potencial na promoção da alfabetização científica dos atores escolares. Para tanto, trouxe para o centro do palco alunos e professores, tornando-os protagonistas do processo de divulgação do conhecimento científico. A Mostra contou com reportagens e textos de divulgação científica, enfatizando o poder da mídia sobre as representações sociais do corpo. 


\subsection{Referencial Teórico}

Durante séculos, a ciência se construiu sobre os pilares do pensamento puramente racional, o qual excluía toda a incerteza e a contradição. Apesar de esta forma de pensar da ciência ter-nos trazido grandes avanços, especialmente tecnológicos, o pensamento científico moderno tem esbarrado em entraves epistemológicos, não possuindo, ainda, recursos heurísticos para sua superação (MORIN, 2011). O pensamento complexo nasceu dessa incapacidade de a ciência moderna oferecer respostas para a totalidade dos diversos fenômenos incompreendidos pelo homem.

O pensamento complexo prima por reconhecer a necessidade de superação de uma ciência que se envereda por caminhos que nem sempre levam aos interesses da sociedade como um todo. Com isso, ganha tônica uma ciência reflexiva que inclui o homem como um elemento indispensável para a construção do conhecimento, contrapondo-se ao egocentrismo e individualismo atuais.

Uma leitura da obra de Morin (2011) permite reconhecer outro ponto crítico do pensamento científico moderno, qual seja, a exclusão do próprio sujeito do processo científico. Morin (2011) descreve o sujeito a partir de sua subjetividade, unindo esta a sua condição biológica. Se a ciência é pensada pelo homem, e este deu-Ihe existência por meio de seu raciocínio, não faz sentido que a ciência continue a excluir os atores sociais e considere apenas o objeto, cuja existência, muitas vezes, também, se deve ao próprio sujeito. O fato é que por intermédio do olhar complexo é possível perceber uma relação de não exclusão e, sobretudo, de dependência entre estes dois elementos, ciência e homem. Ocorre que o conhecimento deveria favorecer a própria ciência, no desenvolvimento das mentes e da qualidade de vida das pessoas. O pensamento complexo defende vários princípios, entre os quais o dialógico, o qual promove a união de áreas historicamente desunidas, porque enuncia que, para a uma maior compreensão de um fenômeno complexo, é necessário um pensamento indissociável entre diversos campos do saber, especialmente, a biologia, a física e a antropologia. A combinação entre o contexto cultural e o histórico favorece um universo de compreensões para um mesmo fenômeno. Este princípio também pode ser dialogado com a filosofia freiriana, tema que passamos a tratar.

A realização da mostra cultural, objeto de estudo deste artigo, buscou considerar a importância da re-humanização dos discentes, por meio de uma metodologia pedagógica que lhes possibilitasse alcançar um maior nível de consciência crítica com relação à ideologia veiculada pelas estruturas 
sociais hegemônicas, razão pela qual fundamos nossas discussões em Paulo Freire, no livro Pedagogia do Oprimido.

Como nossa prática pedagógica propiciou espaços para a construção de um estado crítico por parte dos alunos, destacamos a importância dada por Paulo Freire (1998) à práxis, considerando ser essa a reflexão e ação dos homens sobre o mundo para transformá-lo. Nesse embate, a conscientização seria o caminho para a libertação. Isso significa que, quando conseguimos inserir o oprimido na realidade opressora, por meio da ressignificação, e discussão, de textos de divulgação científica, com temas selecionados que atendam aos objetivos das aulas, estamos favorecendo a construção do estado crítico de consciência.

O uso da divulgação científica da perspectiva freireana se justifica na medida em que "Quanto mais as massas populares desvelam a realidade objetiva e desafiadora sobre a qual elas devem incidir sua ação transformadora, tanto mais se 'inserem' nela criticamente" (Freire, 1998, p. 40). Vivenciar as temáticas da cultura corporal a partir de uma fundamentação científica pode se constituir em uma estratégia criativa em favor da consciência corporal crítica.

Nas últimas décadas, temos escrito nossa história de forma tão dinâmica que também sentimos necessidade de desvelar quem são os opressores do novo mundo. Com a globalização das economias, surgiram grandes corporações industriais, possuidoras do poder de influência nas diversas dimensões de nossas vidas. Elas controlam a política, a economia, a vida social, ditam as regras sobre o que devemos comer, vestir e como devemos ser. O combustível que alimenta este movimento é o consumo. Neste caso, os opressores se apresentam como as grandes corporações que precisam concretizar a sua dominação por meio do controle do imaginário das pessoas por intermédio dos meios de comunicação de massa. Uma forma de libertação dos oprimidos partiria das discussões em direção à tomada da consciência crítica em relação ao modo como a imagem do corpo vem sendo tratada em nossa sociedade.

Nesse processo, o diálogo se constitui como uma condição sine qua non para a concretização de qualquer proposta libertadora. Os oprimidos devem ser os exemplos de si mesmo, pois não faz sentido buscar um modelo de novo homem, fruto da libertação da consciência, entre aqueles que oprimem (FREIRE, 1998). Assim, foi necessário provocar discussões contextualizadas nas vivências e experiências dos discentes, permitindo-Ihes mergulhar no mundo dos opressores, para, a partir 
da sua realidade, reconhecerem-se como oprimidos. Por meio da Pedagogia do Oprimido lançamos mão de uma via filosófica para conduzir nossas ações didáticas de modo a proporcionar ao educando a compreensão crítica de conceitos de cultura corporal, destacando a artilharia ideológica da mídia na disseminação de conceitos desumanos sobre o trato com o corpo.

A libertação seria o processo capaz de envolver a todos, pois, "ninguém se liberta sozinho, os homens se libertam em comunhão" (FREIRE, 1998, p. 52). A liberdade deve vir por intermédio da prática e não somente no plano teórico. Desta forma, por intermédio das ações realizadas, teremos a aproximação com a práxis. Em nosso caso, após tratarmos os conteúdos e promovermos o diálogo crítico, entre outras ações, os alunos poderão tomar decisões acerca de suas vidas e fazer suas escolhas. Para essa tomada de decisão, concorre a educação problematizadora, a qual desafia a curiosidade inerente ao ser humano, vez que o ato de criar faz parte de nossa vocação ontológica. Na problematização, professores e alunos podem interagir na busca de soluções e construírem seu conhecimento, a partir do olhar compartilhado do mundo.

A educação problematizadora enxerga o homem como algo inconcluso graças ao seu estado de estar sendo. Sua inconclusão deriva de seu estado de ser histórico, com uma existência construída ao longo dos anos e, portanto, sempre inacabada (FREIRE, 1998, grifo do autor). Neste ato, ao considerar o homem como ser histórico, a abordagem sócio-histórica dos conteúdos possibilitará ao educando a percepção de continuidade e da incompleteza da vida. Esta tomada de consciência abre ao aprendiz todo o mundo real, pois este passa a ver-se a si mesmo em sua real condição e descobre, ainda, que pode ser sujeito de sua história, ao invés de mero participante passivo de sua existência.

\subsection{O Ensino de Ciências}

Ao reservarmos neste estudo um espaço para o trato das intervenções pedagógicas em ciências, julgamos ser de suma importância nos reportar às ideias de Delizoicov, Angotti e Pernambuco, na obra intitulada Ensino de Ciências: Fundamentos e métodos (2007), as quais subsidiaram a construção da sequência didática para abordagem dos textos de divulgação científica, desenvolvida nas disciplinas de Geografia, Artes, História, Ensino Religioso e Ciências na oitava série do ensino fundamental da Escola Estadual de Ensino Fundamental Germano André Lube, a qual culminou com a realização da mostra cultural "Gente e corpo". 
Tendo em vista que a educação física, como uma área específica, cujas bases epistemológicas se encontram nas áreas da biologia, antropologia, educação, sociologia e filosofia, legitima-se como ciência a partir de suas contribuições sócio-históricas na elaboração de uma das infindáveis formas em que a cultura se apresenta - a expressão corporal como forma de linguagem (Coletivo de Autores, 1992), esta pesquisa buscará fincar, nesses pressupostos, seus fundamentos.

Os temas tratados pela sequência didática desenvolvida nessa pesquisa são relevantes para a compreensão de alguns aspectos relacionados à formação da consciência crítica sobre a cultura corporal. Nosso estudo planejou enriquecer as discussões sobre as variadas facetas em que se apresenta a imagem do corpo humano em nossa sociedade, desvelando-as por meio do olhar combinado da Educação Física com outras disciplinas da educação básica.

Ao compreendermos a expressão corporal como uma forma de linguagem, cabe, ainda, destacar que, neste universo complexo do conhecimento, o estudo da estética do corpo deve ser compreendido como parte integrante do todo que compõe a expressão corporal. Esta ideia tornase mais profícua quando tentamos conceber o corpo na ausência de movimento. 0 movimento corporal nunca cessa, pois é o movimento da vida.

No percurso do ensino de ciências e da concretização deste trabalho, consideremos também as interações privilegiadas que ocorrem dentro do espaço escolar. Assim, toda comunidade escolar estabelece uma relação íntima com o conhecimento, de forma que sua construção ocorre pelo choque entre os conhecimentos prévios e o conhecimento sistematizado possibilitado pela escola. De acordo com Delizoicov, Angotti e Pernambuco (2007), estas interações podem se constituir de três dimensões: a epistemológica, a educativa e a didático-pedagógica.

Nosso aluno deve ser concebido como sujeito epistêmico já que é capaz de auto-organizar-se com estruturas cognoscitivas tais que Ihe permitam produzir, e acumular, conhecimento. É concebido como sujeito ontológico sob o ponto de vista de se constituir com as características que são únicas aos seres humanos. Essas condições fazem do nosso aluno um sujeito não neutro, já que se constitui como "um sujeito coletivo à medida que interage, estabelecendo relações com o meio físico e social pelas quais se apropria de padrões quer de comportamento quer de linguagem, para uma abordagem do objeto do conhecimento" (DELIZOICOV; ANGOTTI; PERNAMBUCO, 2007, p. 184). 
O aluno, como sujeito cognoscitivo, constitui seus vínculos com os objetos de estudo por meio do conhecimento prévio que traz em seu acervo cultural. Tais conhecimentos constituem um excelente ponto de partida para a aprendizagem, ensejando a construção do saber por meio do conflito entre o senso comum (cultura primeira) e a cultura elaborada.

A dimensão educativa das interações nos conduz à adoção de uma abordagem temática dos conteúdos para que consigamos proporcionar a ocorrência de rupturas com o senso comum dos alunos. Nesse aspecto, devemos considerar como ponto de partida os chamados conhecimentos primeiros dos alunos que serão confrontados com a cultura elaborada apresentada pelo professor.

Para estabelecer esta dinâmica de atuação docente, os autores sustentam que existem algumas possibilidades didático-metodológicas que direcionam este trabalho, mas recomendam um planejamento das ações, baseado na dinâmica dos chamados "momentos pedagógicos". Assim, diferenciam três destes momentos: problematização inicial, organização do conhecimento e aplicação do conhecimento.

A problematização inicial parte do conhecimento que os alunos apresentam sobre o tema em questão. Alunos devem ser encorajados a expor suas concepções enquanto o professor os incentiva por meio de perguntas que alimentam discussões. No segundo momento, o da organização do conhecimento, o professor seleciona os conteúdos que são necessários para a compreensão dos questionamentos apontados na fase anterior. Finalmente, após a concretização do segundo momento, nosso processo de exploração do conhecimento chega à fase de sua aplicação. Assim, os autores sugerem que esta fase deve se destinar a abordar sistematicamente o conhecimento construído pelo aluno.

\subsection{A Divulgação científica e a construção da cultura científica}

A divulgação científica tem como meta a popularização da ciência, contribuindo para a alfabetização científica. Para Demo (2010), a educação é um meio de libertação por criar oportunidades de superação pessoal. Entretanto, esta mesma educação tem servido tanto como um instrumento reprodutor do modelo econômico neoliberal, quanto como estrutura necessária para mantê-lo. 
Para existir, o modelo neoliberal traz consigo um sofisticado sistema de alienação, manutenção e controle, instaurando uma nova ordem para sociedade. Em um mundo corrompido pelas máximas capitalistas que condicionam os pensamentos à finalidade última do consumo, limitados são os recursos educativos que atuam no sentido de elucidar esta influência em todas as dimensões da vida humana. A cultura corporal, quando discutida, é um assunto colocado, à revelia, à margem dos conteúdos eleitos como mais relevantes à formação mecanicista praticada nas escolas. A cultura corporal, tal como outros conhecimentos que são desprezados pelos currículos formais, é elemento imprescindível na concretização da educação científica. O grande desafio está em formar alunos pesquisadores em um país onde nem mesmo os professores são estimulados a produzir conhecimentos. Como falar de ciência e não fazer pesquisa? No Brasil, onde a educação é compreendida quase que exclusivamente como atividades de ensino, a pesquisa um luxo de poucas instituições. (DEMO, 2010).

\subsection{Divulgação Científica e seu papel no ensino de ciências}

Neste cenário, a divulgação científica figura como um caminho viável, alternativo àquele já praticado, para que a ciência tenha um trato diferenciado dentro da escola. A questão aqui colocada é: como a divulgação científica pode auxiliar na alfabetização científica? Entretanto, antes de responder a esta questão, precisamos um conceito mais seguro sobre a divulgação científica.

Silva, Arouca e Guimarães (2002 p.157) pontuam a necessidade de se popularizar a ciência ao grande público, pois, sem o conhecimento científico, a população é facilmente ludibriada pelo discurso tecnocrata. A sociedade precisa compreender que a ciência está inegavelmente atrelada às questões políticas; não é possível exercer a cidadania sem o mínimo de conhecimento sobre as questões científicas de interesse global. "Essa questão torna-se crucial, quando se constata o elevado nível de alienação e analfabetismo científicos presentes na sociedade moderna."

A divulgação científica ainda dá os seus primeiros passos em relação a sua contribuição à educação. Por este motivo, tanto as suas responsabilidades quanto a sua definição têm sido frequentemente debatidas em eventos científicos da área de Ensino. Para tentarmos uma maior aproximação com a questão, tomemos emprestadas as palavras de Silva (2006 p. 57-58) que a conceitua, sem pretensões peremptórias, como 
O que chamamos de divulgação científica é um reflexo de um modo de produção de um conhecimento restringido e, consequentemente da constituição de um efeito-leitor específico relacionado à institucionalização, profissionalização e legitimação da ciência moderna, e que opõe produtores e usuários/consumidores e cria a figura do divulgador, que viria, imaginariamente, restabelecer a cisão e minimizar a tensão instaurada ao longo da história no tecido social da modernidade. Essa cisão não é mantida sem tensão, sem a (re)produção tensa de um imaginário que a mantém. É nesse imaginário que trabalha a divulgação científica.

Aqui, fica clara a existência de dois lados. Em um dos extremos está o cientista, reconhecidamente o agente produtor do conhecimento científico. No outro extremo, encontram-se aqueles a quem se dirige a divulgação científica, a qual funciona como um elemento de interlocução entre as duas partes.

Para Vogt (2011), a divulgação científica insere-se em um contexto mais amplo, qual seja, o da cultura científica. Assim, sem a pretensão de formalizar um conceito para este termo, nos apoiaremos neste autor quando compreende a cultura científica como

O conjunto de fatores, eventos e ações do homem nos processos sociais voltados para a produção, a difusão, o ensino e a divulgação do conhecimento científico constitui as condições para o desenvolvimento de um tipo particular de cultura, de ampla generalidade no mundo contemporâneo (VOGT, 2011, p. 7).

Em um mundo globalizado, é relevante a necessidade de popularização da ciência e tecnologia, pois são pré-requisitos para a inserção dos cidadãos nos debates da sociedade moderna. Cabe à divulgação científica o papel de popularizar a ciência e formar a cultura científica, por meio de uma linguagem que seja apropriada para cada espaço que pretenda alcançar. Por acreditar no potencial educativo da divulgação científica, seguimos uma tendência crescente na área de educação, em que alguns professores já utilizam a divulgação científica como um elemento valioso no trato de temas da ciência no meio escolar. Optamos por utilizar textos, ressignificando este material, tornando-os instrumentos pedagógicos capazes de nos proporcionar um ponto de apoio para a inserção dos conteúdos que debatemos na sequencia didática e na mostra cultural. Nesta direção, utilizamos textos que tratavam de temas científicos necessários ao desenvolvimento de nossa sequência didática, tais como: religião, cultura, etnia, entre outros.

As obras de Attico Chassot se configuram como uma das principais fontes de estudo sobre a alfabetização científica no Brasil. Este autor defende que a ciência deve ser democratizada ao 
máximo, desde o início da escolarização, de maneira clara, facilitadora e prazerosa no processo de ensino-aprendizagem. Dessa maneira, o autor compreende que a alfabetização científica nas escolas é um princípio de cidadania, com vistas à transformação social das comunidades a que pertencem os estudantes.

Assim defende Chassot:

Amplio mais a importância ou as exigências de uma alfabetização científica. Assim como se os alfabetizados em língua materna sejam cidadãs e cidadãos críticos, em oposição, por exemplo, àqueles que Bertolt Brecht classifica de analfabetos políticos, seria desejável que os alfabetizados cientificamente não apenas tivessem facilitada a leitura do mundo em que vivem, mas entendessem as necessidades de transformá-lo em algo melhor [...] (CHASSOT, 2003, p. 94).

Para este autor, a ciência uma linguagem para facilitar nossa leitura do mundo, e ser alfabetizado cientificamente significa saber ler a linguagem em que está escrita a ciência. Deste ponto de vista, alfabetização científica seria possuir a habilidade de compreender as diversas textualidades sob as quais se reveste a ciência. Compreender a ciência como texto significa compreender a cultura como um sistema semiótico, concordando com o que nos apresenta Geertz (1978), para quem a cultura seria uma teia de significados constituída pelo homem, a qual é por este construída ao mesmo tempo em que possui o condão de construí-lo.

Chassot (2003) dispõe que um analfabeto científico seria aquele incapaz de proceder à leitura do universo, e alfabetização científica seria uma proposta de corrigir ensinamentos distorcidos e fazer previsões sobre as transformações que ocorrem na natureza. O autor sugere um olhar sobre as múltiplas interconexões entre as ciências naturais e as sociais. Assim, quando propiciamos o entendimento ou a leitura dessa linguagem, fazemos alfabetização científica.

Tornar a ciência mais acessível ao entendimento de crianças e jovens significa acreditar que as produções científicas nacionais sejam pensadas para melhorar a situação de vida em todos os seus aspectos essenciais - moradia, transporte, economia, alimentação, lazer etc. Isso, porque a educação se torna plena quando os saberes acadêmico-científicos se imbricam com os saberes populares. Na medida em que estes saberes dialogam, surgem ações em favor de transformações socioambientais capazes de dar sentido às comunidades, tornando-as mais harmônicas e humanizadas. Neste ponto, consideramos pertinente elencar o princípio denominado de popularização da ciência que complementa o debate acerca da alfabetização científica e se 
coaduna com o pensamento freireano presente neste trabalho. A proposta de desenvolver atividades didáticas capazes de promover a alfabetização científica demanda uma metodologia baseada na interação humana.

Para Chassot (2003) as explicações científicas podem estar em diversos locais para entendermos o mundo em que vivemos. A ciência, por ser uma forma de linguagem, tentará explicar parte destes acontecimentos na natureza, portanto, precisamos dominar essa linguagem. Para o autor, a alfabetização científica é uma das dimensões que servirá para privilegiar alternativas na educação que busquem contemplar condições para que alunos e alunas compreendam as manifestações do universo, corrigindo ensinamentos distorcidos. Deve-se entender que, nesta proposta da ecologia dos saberes, a alfabetização cientifica também se alicerça na perspectiva da popularização da ciência.

Lorenzetti e Delizoicov (2001) possibilitam uma reflexão em seus estudos sobre o papel da alfabetização científica no resgate da cidadania, a fim de fazerem considerações sobre a alfabetização científica no início do ensino fundamental em razão da carência de referências nesta fase de formação. Para os autores é possível desenvolver uma alfabetização científica nas séries iniciais do ensino fundamental, antes mesmo de o aluno dominar a escrita, inclusive auxiliando no seu processo de aquisição desta por meio da ampliação de sua cultura. E tomam como definição de alfabetização científica a que "tornará o indivíduo alfabetizado cientificamente nos assuntos que envolvem a Ciência e a Tecnologia, ultrapassando a mera reprodução de conceitos científicos, destituídos de significados, de sentidos e de aplicabilidade" (LORENZETTI; DELIZOICOV, 2001, p. 4). A alfabetização científica pode ser ampliada por meio de documentários, sobre ciência, com o uso de teatro em sala de aula em encenações de peças sobre o meio ambiente englobando a experiência anterior do aluno.

Até aqui apresentamos as bases sobre as quais nos apoiamos para compreender o conceito de Alfabetização Científica, defendendo que esta deve ser incentivada na educação básica, por meio de ações que podem ser desempenhadas para que o ensino nestas etapas permita aos alunos trilharem o caminho rumo à construção de uma cultura científica. $O$ ensino de ciências não deve almejar somente a formação de futuros cientistas, mas possibilitar aos estudantes a tomar decisões em sua vida pessoal e em sua vida política, o que não tem ocorrido atualmente 
(SASSERON;CARVALHO, 2008). A maioria das pessoas só vai se inteirar sobre determinado tema, a mineração e seus impactos ambientais, por exemplo, quando algum desastre ocorrer. Em épocas de instalação de mineradoras, na vizinhança de pequenas cidades, quando a população é convidada a participar das audiências públicas, muito pouco discute sobre impactos ambientais e sobre consequências das atividades mineiras. A maioria da população vai em busca de emprego ou de vantagens pessoais para si ou para suas organizações. Precisamos reverter esse quadro, incentivando ações pedagógicas que possibilitem os alunos a trabalhem ativamente resolvendo e/ou discutindo problemas referentes às ciências e às suas tecnologias.

Sasseron e Carvalho (2008, p. 72) defendem que o ensino de Ciências não pode se restringir à "transmissão de conhecimentos, mas deve mostrar aos alunos a natureza da ciência e a prática científica e, sempre que possível, explorar as relações existentes entre ciência/tecnologia/sociedade." As autoras discorrem sobre pressupostos teóricos importantes que podem ser utilizados para indicar algumas ações e habilidades produzidas para resolução de um problema, as quais podem resultar num processo de alfabetização científica.

\section{PERCURSO METODOLÓGICO}

O IFES possui convênio com as Escolas Estaduais, o que favoreceu o desenvolvimento da sequência didática em turmas de 8 o ano de ensino fundamental, do turno vespertino. Quanto à natureza, trata-se de um estudo qualitativo (Gil, 1996). Dada a natureza qualitativa de nosso estudo, não pretendemos apontar possíveis soluções para o problema proposto, mas compreendê-lo melhor. Quanto aos procedimentos técnicos, elegemos a pesquisa etnográfica escolar, a qual apresenta muitas semelhanças com o estudo de campo. O fato de nossa pesquisa acontecer em sala de aula the confere um atributo que facilmente a delinearia como um estudo de campo, exceto pelo fato de que, nosso foco, está na "descrição de um sistema de significados culturais de determinado grupo (ANDRÉ; LUDKE, 2013, p. 15).

Nesta pesquisa, utilizamos as aulas de Educação Física de duas turmas de $8^{a}$ série do ensino fundamental para desenvolver uma sequência didática composta por 12 aulas, culminando com um mostra cultural na última aula, objeto deste artigo. Esta mostra cultural foi utilizada como ferramenta de avaliação caracterizando o término da sequência didática, e como espaço para socialização da ciência. 
A sequência didática conteve aulas que tematizaram a cultura corporal veiculada pela mídia e suas influências no modo de vida dos adolescentes. Estudamos a formação das concepções sobre o corpo tratada pela cultura de massa. Foram favorecidos momentos de conflitos entre as duas concepções de cultura, midiática e científica, buscando, no debate, a exposição de ideias dos alunos. Desta forma, caracterizamos esta pesquisa etnográfica como escolar, pois o uso da etnografia em educação deve ter a preocupação de pensar o ensino e a aprendizagem dentro de um contexto cultural amplo (ANDRÉ; LUDKE, 2013, p. 15).

O objeto material deste artigo é a mostra cultural que ocorreu como culminância da sequência didática desenvolvida. Trata-se, pois, de um estudo de caso, com procedimentos do tipo observação participante e, como instrumentos de coleta, utilizamos o diário de campo, coletamos imagens, aplicamos uma entrevista semi-estruturada e lançamos mão de uma grelha de observação. Com o objetivo de captarmos o olhar dos professores quanto à realização da mostra, utilizamos a entrevista semi-estruturada, e para registrar os avanços no que diz respeito à alfabetização cientifico dos alunos, lançamos mão da grelha de observação, tomando como pressuposto a técnica desenvolvida por Leonor (2012). O Quadro 1 a seguir apresenta uma visão geral dos instrumentos e técnicas utilizados na pesquisa.

Quadro 1. Resumo das técnicas e instrumentos de coleta de dados empregados durante a investigação da prática pedagógica.

\begin{tabular}{|c|c|c|c|}
\hline Investigação & Técnicas & Instrumentos & Referências \\
\hline \multirow{4}{*}{$\begin{array}{l}\text { Investigação } \\
\text { Qualitativa } \\
\text { Tipo: } \\
\text { Estudo de Caso }\end{array}$} & Observação participante & Anotações no diário de bordo & André; Ludke (2013) \\
\hline & $\begin{array}{l}\text { Entrevista } \\
\text { estruturada }\end{array}$ & Entrevista de Grupo Focal. & André; Ludke (2013) \\
\hline & Imagens & $\begin{array}{l}\text { Fotografias como registro dos } \\
\text { momentos da Mostra cultural. }\end{array}$ & Bardin (2011) \\
\hline & observações & $\begin{array}{l}\text { Anotações produzidas nos } \\
\text { diários de bordo e grelha de } \\
\text { observação }\end{array}$ & Leonor (2013) \\
\hline
\end{tabular}

Fonte: os autores (2015).

A discussão dos dados ocorreu numa linha analítico-reflexiva. A fase de pré-análise compreendeu a organização do material coletado. Em nosso caso, procedemos com a leitura do diário de campo e a organização dos instrumentos aplicados aos professores e a grelha de observação para coleta dos relatos dos alunos, a fim de captarmos momentos que revelavam os avanços na alfabetização 
científica. Durante a seleção do material, procuramos cumprir com as regras exaustividade, representatividade dos sujeitos da pesquisa, homogeneidade e pertinência (Bardin, 2009).

\subsection{Local da Pesquisa}

A realização da mostra cultural como culminância da sequência didática ocorreu na escola estadual de ensino fundamental Germano André Lube localizada no Bairro das Laranjeiras em Jacaraípe, no município da Serra-ES. Desde fevereiro de 2013, quando recebeu um investimento do governo estadual de aproximadamente 3 milhões de reais, a EEEF Germano André Lube ampliou sua capacidade de atendimento para 921 atores escolares, entre alunos em idade regular e educação de jovens e adultos (EJA). Nos últimos anos, esta escola recebeu dois prêmios do programa "Boas Práticas na Educação" promovido pela secretaria estadual de educação do estado do Espírito Santo. É uma escola bem aberta a propostas inovadoras que contemplem um ensino de qualidade, fato este, comprovado pela boa receptividade a nossa presença como pesquisadores.

\subsection{Espaço físico e infraestrutura}

A escola possui 12 salas de aula distribuídas entre dois andares de um mesmo prédio. Tanto no período matutino quanto no período vespertino, as salas do primeiro andar foram reservadas para as séries iniciais do ensino fundamental; as salas do segundo andar ficaram para as turmas mais avançadas. O período noturno atende exclusivamente à educação de jovens e adultos. Atualmente a escola conta com salas específicas como laboratório de informática, auditório, quadra de esportes, refeitório, laboratório de ciências, biblioteca e sala de recursos. A sala dos professores é ampla, climatizada e equipada com dois computadores. As pedagogas também possuem uma sala reservada para suas atividades. A quadra poliesportiva favorece as atividades práticas inerentes à disciplina de educação física. Possui isolamento por grades e arquibancada com espaço para aproximadamente 150 alunos. A escola possui biblioteca, auditório e refeitório.

\subsection{Recursos humanos}

A equipe da EEEF Germano André Lube é formada por um diretor, cinco coordenadores, sendo dois no turno matutino, dois no turno vespertino e um no turno noturno; cinco pedagogos, sendo dois no turno matutino, dois no turno vespertino e um no turno noturno; três auxiliares de 
biblioteca, um em cada turno escolar, três secretárias que se revezam para atender os três turnos, e um auxiliar de secretaria que atende no turno noturno; dois professores de educação especial atendendo nos turnos matutino e vespertino; dez auxiliares de serviços gerias e quatro cozinheiras; no momento da pesquisa, nenhum estagiário nem tampouco técnicos de informática; 60 professores todos com nível superior e dois seguranças.

\subsection{Caracterização dos alunos e das famílias}

A população está inserida em um meio social onde violência manifesta-se com toda sua diversidade, especialmente aquelas motivadas pelo tráfico de drogas. A referida escola atende aproximadamente a 921 alunos distribuídos entre três turnos de funcionamento. Desta forma, a faixa etária possui grande variação, situando-se entre 7 a 60 anos. Esta clientela apresenta origens das mais variadas, sendo, na sua maioria formada por imigrantes de diversos estados do Nordeste e de alguns países latinos como Haiti. Também há relatos de alunos de origem indígena. Identificamos na escola casos extremos de descuido com os jovens. Desta forma, uma fatia dos sujeitos deste estudo está inserida em instituições familiares em que são expostos a realidades adversas como: pais que fazem sexo na frente dos filhos, uso e venda de drogas, contato com armas, agressões físicas e verbais dos pais (quando ainda moram juntos), membros da família que são detentos da justiça, entre outros.

\subsection{Sujeitos}

A participação dos professores das disciplinas envolvidas nesta pesquisa foi de fundamental importância para a concretização desta proposta, que envolveu as áreas de Geografia, Ensino Religioso, Artes, Ciências e História. Nossa proposta foi atuar junto a estes docentes, no espaço de sua sala de aula, contando com sua participação voluntária.

Neste universo escolar, optamos por acompanhar duas turmas mistas de oitavo ano do ensino fundamental com 40 alunos cada uma. Nos momentos iniciais, revelamos aos alunos, sucintamente, a programação de aulas de que participariam no transcurso da sequência didática. No contato inicial, ficou evidente a característica das turmas com relação a sua participação e à aceitação da proposta. A oitava série 2 foi mais receptiva ao trabalho. A outra turma, apesar de mais ruidosa, também demonstrou entusiasmo em nosso contato inicial. Acreditamos que este 
momento informal foi determinante para o estabelecimento de um laço afetivo e para a conquista da confiança de parte da turma.

\subsection{A Sequência Didática}

A sequência didática se constitui em uma alternativa criativa ao modelo educacional tradicional. Optamos por construir uma sequência didática capaz de reunir os saberes necessários à compreensão do fenômeno da cultura corporal na atualidade. Outra constatação que se fez presente na elaboração desta sequência de aulas foram as reflexões relativas ao pensamento complexo de Edgar Morin. Esta forma de conceber a ciência defende a natureza holística do conhecimento e recomenda seu trato de forma interdisciplinar e transdisciplinar, a fim de reunir a maior parte dos saberes necessários para uma compreensão mais fiel de um determinado objeto ou fenômeno. A interdisciplinaridade assumiu uma posição relevante na medida em que se constitui como o amálgama de conhecimentos necessários para um olhar mais seguro sobre cultura corporal tratada pela mídia. Esta compreensão holística se situa em uma zona de conhecimentos onde se fazem presentes as disciplinas de Geografia, Ensino Religioso, Ciências, Artes e História. Ao mesmo tempo em que cada área contribui para a compreensão aproximada da cultura corporal manipulada pelos meios de comunicação, cada uma possui sua forma particular de olhar o tema.

A teoria pedagógica libertadora proporciona um apoio filosófico à proposta de uma educação incorporada à concepção desta sequência didática. Os discentes se encontram mergulhados em uma realidade ideológica, forjada pela mídia e pelas grandes corporações, que extraem seus lucros a partir da disseminação de conceitos equivocados sobre a forma como devemos compreender nosso corpo. O planejamento a partir de um tema gerador também se constitui em mais uma contribuição do pensamento de Paulo Freire. O tema funcionou como móbil para seleção dos subtemas, objetivos, conteúdos e métodos de trabalho. A abordagem a partir de um tema gerador favorece a escolha dos caminhos para a compreensão de fenômenos ou objetos.

O tema gerador desta sequência didática foi selecionado a fim de proporcionar a discussão de uma situação-problema que se apresenta a partir da seguinte suposição: a visão do corpo pelo homem diferencia-se de cultura para cultura, de tempos em tempos. Na atualidade, o corpo sofre um processo de vitimização ao ser padronizado. Assim, as pessoas sentem-se impelidas a 
apresentarem-se esteticamente segundo padrões estabelecidos pelas grandes corporações. É claro que, para a maioria da população, encaixar-se dentro de um modelo torna-se uma missão muitas vezes impossível de ser alcançada. Portanto, esta sequência se propõe a discutir a seguinte situação-problema: Você está feliz com seu corpo?

A divulgação científica funcionou como pilar motivador para as discussões inerentes a nossa programação. O material de referência baseado em textos e vídeos nos possibilitou explorar suas informações, a partir das quais desenvolvemos os conteúdos peculiares a cada disciplina. Em nosso estudo, a divulgação científica foi tratada como um elemento provocador da curiosidade, para que os alunos percebam a necessidade de aprofundar seus estudos sobre os temas tratados. A culminância da sequência didática ocorreu em um evento também no campo da divulgação científica, qual seja, a realização de uma mostra cultural. Este evento foi organizado a partir de uma exposição programada, onde os alunos orientaram a leitura do público. O quadro 2 apresenta um resumo da Sequência didática que foi desenvolvida em 11 aulas, sendo a 12a aula utilizada para a Mostra Cultural.

Quadro 2. Sequência didática desenvolvida na pesquisa. Modelo estrutural de uma Sequência Didática proposto por Guimarães e Giordan (2011).

\begin{tabular}{|l|l|}
\hline \multicolumn{2}{|l|}{ Sequência Didática Interdisciplinar: Gente e corpo } \\
\hline Título & Gente e corpo \\
\hline Tema gerador & A concepção da imagem corporal na sociedade moderna \\
\hline Subtemas & $\begin{array}{l}\text { As influências neoliberais, históricas e culturais na concepção da imagem do } \\
\text { corpo (aulas 1, 2,3 e 4). } \\
\text { A origem do preconceito e da intolerância com relação às diferenças de } \\
\text { fenótipo e de aparência visual (aulas 5 e 6). } \\
\text { Riscos para a saúde em decorrência da busca desenfreada pelo corpo ideal } \\
\text { criado pela mídia (aulas 7, 8, 9, 10 e 11). }\end{array}$ \\
\hline Problematização & $\begin{array}{l}\text { A visão do corpo pelo homem sempre variou de cultura para cultura. Na } \\
\text { modernidade, o corpo sofre uma vitimização ao ser padronizado em suas } \\
\text { formas e adereços. Assim, as pessoas sentem-se compelidas a apresentarem-se } \\
\text { esteticamente segundo estes padrões. É claro que para a maioria da população } \\
\text { encaixar-se dentro de um modelo torna-se uma missão muitas vezes impossível } \\
\text { de ser alcançada. Neste sentido, esta sequência se propõe a discutir a seguinte } \\
\text { situação-problema: Você está feliz com seu corpo? }\end{array}$ \\
\hline Objetivos Gerais & $\begin{array}{l}\text { Apresentar uma abordagem acerca das diferenças entre as pessoas em sua } \\
\text { dimensão corporal de forma integrada aos conteúdos da educação científica, }\end{array}$ \\
\hline
\end{tabular}




\begin{tabular}{|c|c|c|c|}
\hline & $\begin{array}{l}\text { finali } \\
\text { mais }\end{array}$ & $\begin{array}{l}\text { to o trabalho } \\
\text { rsas manifest }\end{array}$ & $\begin{array}{l}\text { m uma mostra cultural tematizada no corpo em suas } \\
\text { es. }\end{array}$ \\
\hline \multicolumn{4}{|c|}{ Conteúdos e métodos } \\
\hline Aula & $\begin{array}{l}\text { Objetivos } \\
\text { Específicos }\end{array}$ & $\begin{array}{l}\text { Disciplina } \\
\text { Conteúdo }\end{array}$ & Momentos pedagógicos \\
\hline 1 & 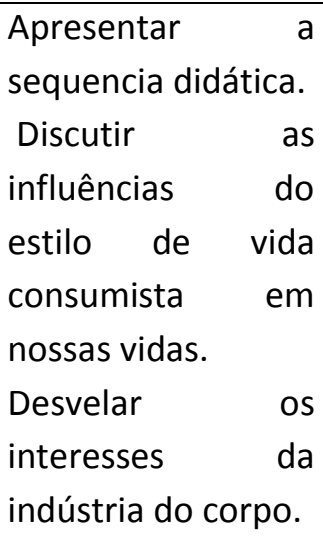 & $\begin{array}{l}\text { Disciplina } \\
\text { Ciências } \\
\text { Conteúdo } \\
\text { Conceitual } \\
\text { Procedimental }\end{array}$ & $\begin{array}{l}\text { M1 - Bate papo informal e abertura com o vídeo } \\
\text { "mente sã em corpo são. Problematização: M2 - } \\
\text { Reflexões a partir do vídeo "A história das coisas". } \\
\text { M3 - Estabelecer um diálogo a partir do questionando } \\
\text { dos alunos sobre a identidade de algumas } \\
\text { corporações que atuam nesta indústria. }\end{array}$ \\
\hline 2 & $\begin{array}{l}\text { Apresentar } \\
\text { influências } \\
\text { mercado } \\
\text { consumista } \\
\text { beleza. }\end{array}$ & $\begin{array}{l}\text { Disciplina } \\
\text { Artes } \\
\text { Conteúdo } \\
\text { Conceitual } \\
\text { Procedimental }\end{array}$ & $\begin{array}{l}\text { M1 - Problematizar sobre as reais necessidades de } \\
\text { consumo } \\
\text { M2 - Destacar nos comerciais apresentados } \\
\text { elementos visuais que visam a ludibriar o expectador, } \\
\text { condicionando-o a compra. } \\
\text { M3 - Criar um slogan para vender um produto de } \\
\text { beleza qualquer. }\end{array}$ \\
\hline 3 & $\begin{array}{l}\text { Situar as } \\
\text { influências da } \\
\text { cultura local e do } \\
\text { momento histórico } \\
\text { na concepção do } \\
\text { ideal de beleza de } \\
\text { uma sociedade }\end{array}$ & $\begin{array}{l}\text { Disciplina } \\
\text { História } \\
\text { Conteúdo } \\
\text { Conceitual }\end{array}$ & $\begin{array}{l}\text { M1 - Problematizar como a visão do corpo varia } \\
\text { culturalmente e socialmente. M2 - Traçar um } \\
\text { percurso histórico do corpo em diferentes tempo e } \\
\text { culturas a partir do texto "Nazismo queria embelezar } \\
\text { o mundo". M3 - Discutir a visão moderna de corpo. }\end{array}$ \\
\hline \multirow[t]{2}{*}{4} & $\begin{array}{l}\text { Apresentar a visão } \\
\text { de corpo feminino } \\
\text { de alguns artistas } \\
\text { como pintores, } \\
\text { escultores e } \\
\text { artesãos. }\end{array}$ & $\begin{array}{l}\text { Disciplina } \\
\text { Artes }\end{array}$ & $\begin{array}{l}\text { M1 - Problematizar sobre como são modificadas as } \\
\text { concepções de beleza, conforme retratadas nas obras } \\
\text { de artistas do período do renascimento. M2 - } \\
\text { Apresentar aos alunos algumas obras famosas, } \\
\text { destacando a variabilidades das formas fazendo uso } \\
\text { do fotodocumentário " a mulher na arte", obtido } \\
\text { junto a versão online da revista Veja. M3 - Promover } \\
\text { um debate onde os alunos sejam provocados a } \\
\text { argumentar a partir dos conhecimentos obtidos no } \\
\text { momento } 2 \text {. }\end{array}$ \\
\hline & $\begin{array}{l}\text { Listar e discutir } \\
\text { sobre } \\
\text { preconceitos }\end{array}$ & $\begin{array}{l}\text { Disciplina } \\
\text { Ensino } \\
\text { Religioso }\end{array}$ & $\begin{array}{l}\text { M1 - Problematizar sobre as formas de preconceitos } \\
\text { motivados pela imagem corporal influenciada pela } \\
\text { religião. M2 - Discutir as particularidades das religiões }\end{array}$ \\
\hline
\end{tabular}




\begin{tabular}{|c|c|c|c|}
\hline 5 & $\begin{array}{l}\text { relacionados a } \\
\text { forma de se vestir, } \\
\text { destacando os } \\
\text { tipos de } \\
\text { composições } \\
\text { estéticas } \\
\text { preconizadas por } \\
\text { algumas religiões }\end{array}$ & $\begin{array}{l}\text { Conteúdo } \\
\text { Conceitual } \\
\text { Atitudinal }\end{array}$ & $\begin{array}{l}\text { que influenciam a imagem corporal de seus adeptos a } \\
\text { partir do texto "O papel da mulher no Islamismo". M3 } \\
\text { - Promover uma discussão que incentive os alunos } \\
\text { argumentarem sobre os estereótipos de imagem } \\
\text { relacionados a alguma religião. }\end{array}$ \\
\hline 6 & $\begin{array}{l}\text { Compreender os } \\
\text { efeitos do Sol no } \\
\text { corpo. }\end{array}$ & $\begin{array}{l}\text { Disciplina } \\
\text { Ciências } \\
\text { Conteúdos } \\
\text { Conceituais }\end{array}$ & $\begin{array}{l}\text { M1 - Problematizar os limites para a saúde da } \\
\text { exposição excessiva x exposição recomendada de sol } \\
\text { M2 - A partir do texto, conhecer as ações benéficas } \\
\text { para o sol no organismo. Apresentar o mecanismo do } \\
\text { câncer de pele. Discutir sobre formas de proteção da } \\
\text { radiação solar e seus efeitos }\end{array}$ \\
\hline 7 & $\begin{array}{l}\text { Discutir algumas } \\
\text { consequências da } \\
\text { busca alienada pelo } \\
\text { corpo ideal. } \\
\text { Identificar dos } \\
\text { efeitos } \\
\text { esteroides } \\
\text { anabólicos para o } \\
\text { organismo. }\end{array}$ & $\begin{array}{l}\text { Disciplina } \\
\text { Ciências } \\
\text { Conteúdo } \\
\text { Conceitual }\end{array}$ & $\begin{array}{l}\text { M1 - Problematizar as razões que levam os jovens a } \\
\text { usar esteroides anabólicos M2 - A partir do texto } 3 \\
\text { "Mulher abusa de anabolizantes e fica com barba e } \\
\text { pequeno 'pênis'”. Explorar o mecanismo de ação dos } \\
\text { hormônios androgênicos no corpo. M3 - Reconhecer } \\
\text { o potencial danoso dos esteroides androgênicos }\end{array}$ \\
\hline 8 & $\begin{array}{l}\text { Estudo de } \\
\text { distúrbios de } \\
\text { autoimagem, } \\
\text { transtornos } \\
\text { dismórficos } \\
\text { corporais das } \\
\text { pessoas } \\
\text { alteram } \\
\text { drasticamente sua } \\
\text { rotina } \\
\text { alimentação } \\
\text { atividades física a } \\
\text { fim de compor um } \\
\text { modelo corporal. }\end{array}$ & $\begin{array}{l}\text { Disciplina } \\
\text { Ciências } \\
\text { Conteúdo } \\
\text { Conceitual } \\
\text { Procedimental }\end{array}$ & $\begin{array}{l}\text { M1 - Problematizar as motivações dos jovens que } \\
\text { sofrem destes distúrbios. M2 - A partir do texto } 6 \\
\text { "Vigorexia e anorexia são motivadas por padrões de } \\
\text { beleza excessivos", discutir os aspectos científicos que } \\
\text { oportunizem uma maior compreensão destas } \\
\text { doenças. M3 - Como reconhecer pessoas que } \\
\text { apresentem pré-disposição para estes distúrbios? }\end{array}$ \\
\hline 9 & $\begin{array}{l}\text { Discutir os riscos de } \\
\text { Procedimentos } \\
\text { cirúrgicos } \\
\text { (plásticas, }\end{array}$ & $\begin{array}{l}\text { Disciplina } \\
\text { Ciências } \\
\text { Conteúdo }\end{array}$ & $\begin{array}{l}\text { M1 - Problematizar os casos de cirurgias que visam à } \\
\text { beleza e cirurgias corretivas de deformidades. Que } \\
\text { tipo de imperfeições poderiam justificar as cirurgias } \\
\text { plásticas? } \\
\text { M2 - A partir do texto 5, compreender o mecanismo } \\
\text { de ação de algumas substâncias, bem como }\end{array}$ \\
\hline
\end{tabular}


Pereira, Campos e Rocha, 2016 - Ensino de Ciências e Matemática

\begin{tabular}{|c|c|c|c|}
\hline & lipoaspiração, etc.) & Conceitual & $\begin{array}{l}\text { funcionamento de algumas células como adipócitos. } \\
\text { Discutir sobre o custo benefício de procedimentos } \\
\text { cirúrgicos e não cirúrgicos }\end{array}$ \\
\hline 10 & $\begin{array}{l}\text { Discutir os reflexos } \\
\text { sociais } \\
\text { psicológicos da } \\
\text { padronização do } \\
\text { corpo (bullying, } \\
\begin{array}{lr}\text { ansiedade, } \\
\text { depressão } \\
\text { timidez) }\end{array}\end{array}$ & $\begin{array}{l}\text { Conteúdo } \\
\text { Conceitual } \\
\text { Atitudinal }\end{array}$ & $\begin{array}{l}\text { M1 - Problematizar sobre o sentimento de tristeza } \\
\text { que algumas pessoas sentem por acreditarem ser } \\
\text { fisicamente inferiores às outras pessoas. } \\
\text { M2 - Vídeo de divulgação científica sobre bullying } \\
\text { exibido no globo repórter. } \\
\text { M3 - Como reconhecer casos de bullying? Qual a } \\
\text { diferença entre depressão e tristeza? O que mais } \\
\text { teme uma pessoa tímida? }\end{array}$ \\
\hline 11 & $\begin{array}{lr}\text { Discutir } & \text { as } \\
\text { diferenças } & \text { étnicas } \\
\text { da } & \text { imagem } \\
\text { corporal } & \end{array}$ & $\begin{array}{l}\text { Disciplina } \\
\text { Geografia }\end{array}$ & $\begin{array}{l}\text { M1 - Problematizar se existem "raças" que tem } \\
\text { privilégios em relação às demais. M2 - A partir do } \\
\text { texto " Composição étnica do Brasil " apresentar as } \\
\text { raízes históricas dos privilégios de algumas etnias. M3 } \\
\text { - Identificar as origens dos privilégios de algumas } \\
\text { raças. }\end{array}$ \\
\hline
\end{tabular}

12 - Mostra cultural: Será realizada uma mostra cultural sobre os temas abordados durante o percurso desta sequência didática. Pais e membros da comunidade foram convidados a participarem do evento.

\begin{tabular}{|c|c|}
\hline Avaliação & $\begin{array}{l}\text { Nossa sugestão é de que a mostra cultural seja avaliada, a partir das contribuições dos } \\
\text { alunos, por todos os professores envolvidos na sequencia didática. }\end{array}$ \\
\hline $\begin{array}{l}\text { Referencial } \\
\text { Bibliográfico }\end{array}$ & $\begin{array}{l}\text { TEXTOS } \\
\text { Texto } 1 \text { - O nazismo queria embelezar o mundo (folha online - folha de São Paulo) } \\
\text { http://www1.folha.uol.com.br/livrariadafolha/2014/09/1513299-nazismo-queria- } \\
\text { embelezar-o-mundo.shtml } \\
\text { Texto } 2 \text { - O papel da mulher no islamismo } \\
\text { http://veja.abril.com.br/idade/exclusivo/islamismo/contexto debate.html } \\
\text { Texto } 3 \text { - Mulher abusa de esteroides e fica com barba e mini pênis. } \\
\text { http://f5.folha.uol.com.br/humanos/2013/10/1360439-mulher-abusa-de-esteroides-e- } \\
\text { fica-com-barba-e-especie-de-mini-penis.shtml } \\
\text { Texto } 4 \text { - Vigorexia e anorexia são motivadas por padrões de beleza excessivos } \\
\text { http://www.minhavida.com.br/saude/materias/2584-vigorexia-e-anorexia-sao- } \\
\text { motivadas-por-padroes-de-beleza-excessivos } \\
\text { Texto } 5 \text { - Composição étnica do Brasil } \\
\text { http://www.brasilescola.com/geografia/composicao-etnica-brasileira.htm } \\
\text { Texto } 6 \text { - Efeitos benéficos e maléficos do Sol } \\
\text { http://educador.brasilescola.com/estrategias-ensino/os-efeitos-beneficos-maleficos- } \\
\text { sol.htm } \\
\text { Vídeo } 1 \text { - A história das coisas } \\
\text { https://www.youtube.com/watch?v=ZpkxCpxKill (parte I) } \\
\text { https://www.youtube.com/watch?v=ZgyNw5plXE8 (parte II) } \\
\text { Vídeo } 2 \text { - Os efeitos do sol } \\
\text { https://www.youtube.com/watch?v=WE b1kOhCqo }\end{array}$ \\
\hline
\end{tabular}


Pereira, Campos e Rocha, 2016 - Ensino de Ciências e Matemática

\begin{tabular}{|l|l|}
\hline $\begin{array}{l}\text { Vídeo 3 - Erros médicos em cirurgias plásticas } \\
\text { https://www.youtube.com/watch?v=4Is995WxalE (parte I) } \\
\text { Vídeo 4 - Bullying e perseguição } \\
\text { https://www.youtube.com/watch?v=M6EQh7WeVHI }\end{array}$ \\
$\begin{array}{l}\text { FOTODOCUMENTÁRIO } \\
\text { Fotodocumentário 1 - A mulher na arte } \\
\text { http://veja.abril.com.br/multimidia/galeria-fotos/a-mulher-na-arte }\end{array}$ \\
$\begin{array}{l}\text { BARBOSA, A.M. Teoria e prática da educação artística. São Paulo: Cultrix, 1995. } \\
\text { DIEGUES JUNIOR, M. Etnias e culturas no Brasil. Rio de Janeiro: Editora BIBLIOEX, 2000. } \\
\text { FAGIOLI, D.; NASSER, L.A. Educação nutricional na infância e na adolescência.2ed.São } \\
\text { Paulo: Editora RCN, 2008. } \\
\text { MINERBI, A. A história ilustrada do nazismo: o poder e as consequências. São Paulo: } \\
\text { Larousse: 2001. } \\
\text { SOARES, C. Corpo e História. 2ed. Campinas: Autores Associados, 2001. }\end{array}$
\end{tabular}
Fonte: os autores (2015).

\subsection{Validação da sequência didática}

Utilizamos, para a validação da nossa SD, as orientações contidas no trabalho de Guimarães e Giordan (2011). Dividimos nosso percurso de validação em quatro etapas: análise prévia, validação a priori, experimentação e validação a posteriori. Durante a análise prévia, nos fixamos nas concepções teóricas que julgávamos de maior relevância para adequarmos nossa SD à proposta de tema. A etapa de validação pelos pares foi realizada com os professores da própria escola envolvida na pesquisa, quais sejam, os docentes das disciplinas de Ensino Religioso, Ciências, Geografia, Artes e História, além da pedagoga da escola. A validação ocorreu em meio à rotina escolar, agravada pelas demandas naturais da escola. Desta forma, optamos por uma abordagem individualizada de cada professor, exceto as professoras de artes e ciências, que foram contribuíram juntas. Apresentamos a sequência com auxílio de um notebook de catorze polegadas. Foram sete slides em power point nos quais condensamos as informações necessárias a compreensão do trabalho.

\subsection{A Mostra Cultural}

A realização da mostra cultural ocorreu como culminância do desenvolvimento da sequência didática, no mês de setembro de 2015. Toda escola foi liberada durante a última aula para 
participar da mostra cultural. O material exposto na Mostra foi confeccionado com antecedência. Nas últimas aulas da sequência didática havíamos solicitado aos alunos que trouxessem imagens e textos sobre o tema de seu trabalho. Para a confecção dos cartazes contamos com a colaboração do professor de História e de Artes. Neste dia, as turmas tinham duas aulas consecutivas de ciências, o que facilitou o trabalho. Mesmo com todo empenho, muitos grupos não conseguiram terminar a tempo seus cartazes. Quando precisamos da quadra, o professor de Educação Física foi bastante colaborativo em não utilizar o espaço para que pudéssemos organizar a mostra cultural, que ocorreu no final da tarde. Uma aluna da quinta série nos perguntou quando chegariam os fisiculturistas, esclarecemos que a mostra cultural era constituída de apresentação de trabalhos. Sua decepção foi evidente. Muitos alunos das oitavas séries se dedicaram com afinco ao projeto. Porém, alguns grupos queriam ver os outros trabalhos e acabaram deixando os seus sem apresentar. O trabalho sobre mensagens subliminares chamou muito a atenção. Tal fato se explica pelas gravuras da Disney que traziam mensagens de estímulo à sexualidade precoce das crianças. Em relação ao quantitativo de professores, poucos foram até a quadra prestigiar o evento.

Os trabalhos sobre esteroides anabolizantes foram muito requisitados. Crianças da quinta série ficaram espantadas com as imagens de pessoas com anorexia. Um grupo que apresentou trabalho sobre as mulheres e o Islamismo mostrou bastante empenho durante a visita dos colegas. Contrariamente aos colegas, optaram por fazer apresentações a pequenos grupos (Figuras 2-3). Uma das professoras participantes da mostra, a Profa Cláudia, elogiou o evento de divulgação, afirmando que os temas eram muito relevantes para os alunos. Acrescentou que a maioria destes temas não possui uma recomendação formal como conteúdos escolares. A seguir apresentamos algumas cenas da Mostra Cultural (Figuras 1, 2 e 3), flagradas desde o preparo até a realização da mostra. 
Figura1. Alunos em Preparação dos trabalhos da Mostra cultural.

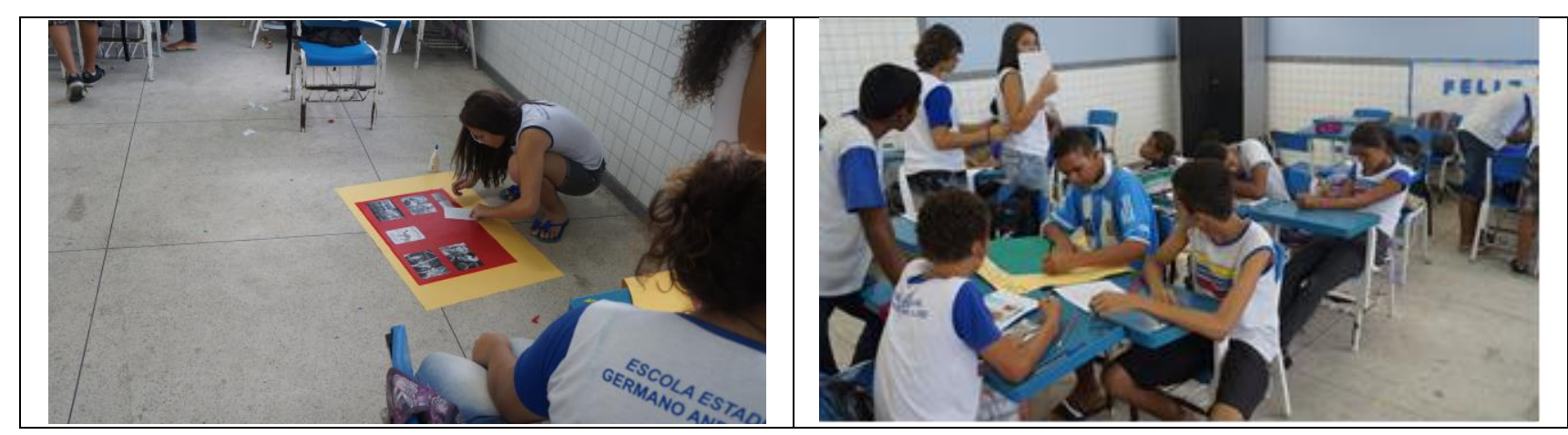

Fonte: os autores (2015)

Figura 2. Cartaz de divulgação da mostra cultural e momentos do evento.

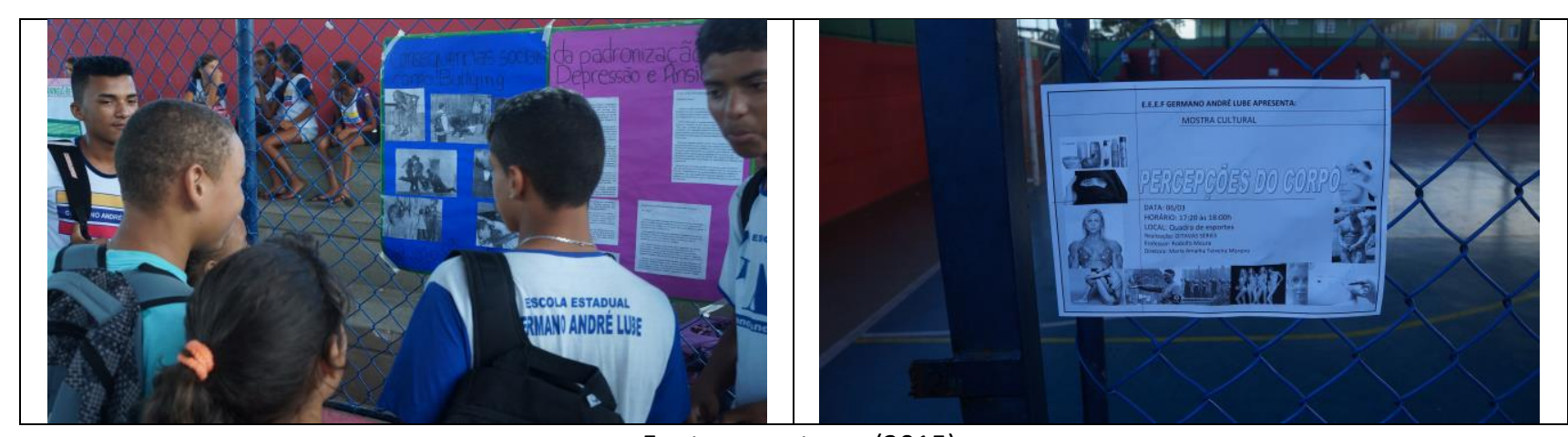

Fonte: os autores (2015)

Figura 3. Mostra cultural.

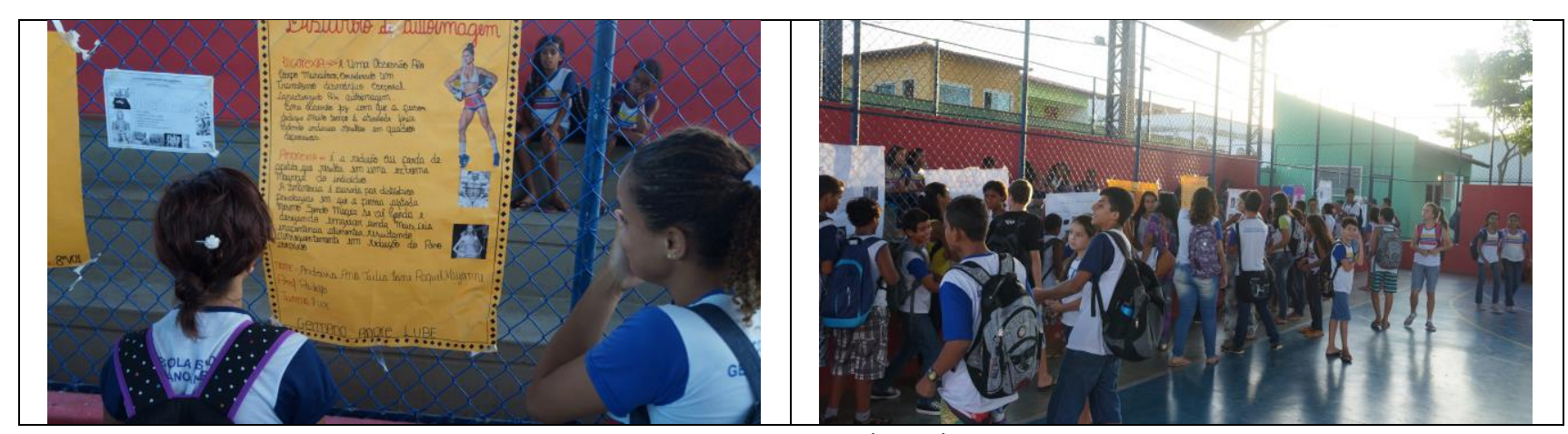

Fonte: os autores (2015).

\section{DISCUSSÃO}

Para a concretização dos objetivos deste estudo, utilizamos duas metodologias de coleta. No decorrer da mostra, coletamos os dados a partir da sugestão de análise proposta por Leonor (2013) com vistas à identificação das categorias de alfabetização científica. A análise pedagógica dos dados transcorreu conforme os pressupostos da alfabetização científica elencados em Sasseron e Carvalho (2008). Foram definidos alguns critérios para analisar o a prática pedagógica, 
considerando as seguintes categorias: compreensão do problema, hipóteses, previsão, explicação, raciocínio lógico e prática social. A análise foi organizada em um quadro, para facilitar a leitura, o qual contemplou momentos captados durante a participação dos alunos na mostra, os quais estavam registrados no diário de campo.

Antes de tudo, colhemos os conhecimentos prévios dos alunos e professores os quais poderiam ser explorados a fim de proporcionar uma aprendizagem crítica no nível da alfabetização científica. Ressaltamos que nesta categoria, consideramos como conhecimentos prévios aqueles obtidos por meio da vivência pessoal na cultura. Os conhecimentos prévios são bem utilizados quando usados como ponto de referência para o feedback entre professores e alunos. Notamos a presença desta categoria em algumas das aulas, conforme apresentamos nos recortes:

No terceiro momento, com as turmas divididas em grupos de quatro alunos, distribuímos várias imagens dos mais variados produtos. Os grupos deveriam escolher aqueles produtos que mais desejavam. Em meio a escolhas óbvias como celulares, óculos escuros, tênis, entre outros, alguns alunos demonstraram uma consciência ambiental ao escolherem artigos como o ventilador no lugar do ar condicionado. Quando questionados sobre a escolha, alegaram que o ventilador economiza mais energia, contribuindo para uma menor degradação do meio ambiente (aula 1 - turmas unidas) (Fonte: diário de bordo).

Este momento, colhido da aula inicial, no desenvolvimento da sequência didática, pode ajustar à exploração deste tema dentro da concepção de educação científica proposta por Demo (2010), em especial, para o seu tratamento dentro de uma proposta que se oriente pela concepção de ciência, tecnologia e sociedade (CTS), conforme defendido por Auler (2011). No contexto de nossas aulas, este momento evidenciou que existe uma conscientização dos alunos em relação a temas que evidenciam o consumo promovido pelas indústrias da beleza.

Questionei um dos alunos sobre o que ele entendia sobre mensagem subliminar. Ele respondeu que é uma forma de propaganda da coca cola (Fonte: Diário de Bordo).

Perguntei por que as pessoas anoréxicas podem morrer. Os alunos disseram que era por falta de nutrientes (Fonte Diário de Bordo).

Perguntei se eles já haviam ouvido falar em anorexia e vigorexia. Um aluno explicou o que entendia sobre o assunto fornecendo uma descrição bem consciente do distúrbio (Fonte Diário de Bordo). 
Quando perguntei quais as raças que conheciam, os alunos descreveram todas as cinco raças utilizadas pelo IBGE, além de raças que não existiam como a "marrom" (Fonte Diário de Bordo).

As passagens revelam um conhecimento embrionário e insuficiente para a explicação científica dos fenômenos. Este nível de inferência dos alunos promove um excelente ponto de partida para o ensino de ciências (DELIZOICOV; ANGOTTI; PERNAMBUCO, 2007). Conhecimentos prévios podem ser facilmente manipuláveis por meio do trato científico do tema, porque é neste momento que se transforma a curiosidade comum em curiosidade epistemológica.

O trabalho pedagógico acerca do corpo permitiu abranger questões sobre esporte, obesidade, alimentação, preconceitos, culturas, assuntos relevantes na formação de competências críticas. Nesse entendimento, a utilização de temas conhecidos dos alunos ou passíveis de discussões, permitindo que conhecimentos de sua vida diária pudessem ser utilizados academicamente, faz do trabalho pedagógico um espaço dinâmico e dialógico. Os temas estudados ofereceram oportunidades para abordar conceitos disciplinares, sistematização de conteúdos e aplicações práticas, assim assuntos aparentemente corriqueiros tornaram-se mais próximos, significativos e catalisadores no desenvolvendo de novas habilidades, sobretudo, alcançando níveis da alfabetização científica. De um modo geral, é possível elencar as habilidades desenvolvidas na atividade pedagógica, a partir do Quadro 3 a seguir, adaptado de Leonor (2013).

Quadro 3. Análise das categorias de alfabetização científica da atividade desenvolvida (Fonte: Elaborado pelos autores, baseado em Leonor (2013).

\begin{tabular}{|c|l|}
$\begin{array}{r}\text { Categorias da } \\
\text { alfabetização } \\
\text { científica }\end{array}$ & \multicolumn{1}{c|}{$\begin{array}{c}\text { Momentos que revelam o avanço na alfabetização científica, colhidos no } \\
\text { decorrer da mostra cultural }\end{array}$} \\
\hline $\begin{array}{r}\text { Propõem } \\
\text { adequadamente } \\
\text { temas para } \\
\text { investigação }\end{array}$ & $\begin{array}{l}\text { Quando os alunos apontaram que alguns rostos dos comerciais que apresentavam } \\
\text { simetria não eram belos. Concluíram, então, que havia outros elementos que deviam } \\
\text { ser julgados como formato do nariz, dentes, olhos etc. } \\
\text { reconheceram a importância de debater o tema e suas consequências. O aluno } \\
\text { consequências como impotência e problemas de coração. }\end{array}$ \\
& $\begin{array}{l}\text { Quando viram trabalhos sobre anorexia, perguntamos se eles saberiam reconhecer } \\
\text { uma pessoa anoréxica. A maioria disse que sim. Entre as descrições, o aluno Matheus } \\
\text { disse que poderia reconhecer pela presença de osteoporose. Outros discordaram e e }\end{array}$ \\
\hline
\end{tabular}




\begin{tabular}{|c|c|}
\hline & $\begin{array}{l}\text { disseram que não dava para ver a osteoporose. Esse assunto revela uma proposta de } \\
\text { estudo. } \\
\text { Quando a mostra havia encerrado, o aluno João Pedro procurou pelo Rodolfo dizendo } \\
\text { que ele tinha uma tia que sofria de anorexia. Ao ser perguntado por que ele achava } \\
\text { isso sua resposta foi que ela estava extremamente magra e que tinha vergonha de } \\
\text { sair de casa. }\end{array}$ \\
\hline $\begin{array}{l}\text { Levantamento e } \\
\text { teste de hipóteses }\end{array}$ & $\begin{array}{l}\text { Quando os alunos vieram perguntar sobre os efeitos da testosterona e dos } \\
\text { hormônios sintéticos, alguns manifestaram o entendimento do porquê do } \\
\text { crescimento do clitóris da mulher. Um aluno perguntou se poderia acontecer algum } \\
\text { problema nesse processo que fizesse com que a pessoa se tornasse homossexual. } \\
\text { Quando perguntamos se nos tempos de hoje, vocês conseguem identificar algum tipo } \\
\text { de imposição de um padrão universal de beleza? Uma aluna disse que, após a SD e a } \\
\text { mostra, passou a acreditar que existe e que isso é camuflado. } \\
\text { Aos serem questionados: Por que algumas religiões possuem formas peculiares de se } \\
\text { cuidar da aparência? uma aluna disse que pode ser a interpretação dos livros } \\
\text { sagrados. }\end{array}$ \\
\hline Comprovação & $\begin{array}{l}\text { A aluna Rafaela disse que quanto mais branca a pele, maior deve ser o fator de } \\
\text { proteção dos filtros solares e mais essa pele é exibida nos anúncios. } \\
\text { Quanto ao trabalho sobre Islamismo, a aluna Marielen lembrou que no início do } \\
\text { Islamismo as mulheres se cobriam por opção, depois passaram a ser obrigadas por } \\
\text { meio dos hadith (declarações de seguidores de Maomé que eram usadas na } \\
\text { composição dos dogmas do islamismo após a sua morte) machistas. } \\
\text { O aluno João constatou que somos preconceitos e isso é herança religiosa, já que na } \\
\text { religião católica não existem mulheres "padres", e que a maioria das religiões são } \\
\text { chefiadas por homens. }\end{array}$ \\
\hline $\begin{array}{r}\text { Justificativa e } \\
\text { explicação }\end{array}$ & $\begin{array}{l}\text { Quando perguntamos se nos tempos de hoje, vocês conseguem identificar algum tipo } \\
\text { de imposição de um padrão universal de beleza? Inicialmente disseram que não havia } \\
\text { conheciam nenhuma pessoa no mundo que fosse como Hitler e quisesse impor um } \\
\text { padrão de beleza. Refiz a pergunta direcionando a atenção para as grandes } \\
\text { corporações do ramo da beleza. Nesse momento eles começaram a falar nomes de } \\
\text { gigantes do setor, especialmente marcas como Victória Secrets, O Boticário, } \\
\text { Monange, Dove, entre outras. As marcas querem rostos que vendem e que atraem, } \\
\text { essa foi a conclusão deles. }\end{array}$ \\
\hline Seriação de dados & $\begin{array}{l}\text { Quando viram o trabalho sobre esteroides anabolizantes, o grupo de alunos } \\
\text { esclareceu que o clitóris era o primeiro órgão a manifestar as consequências do uso. } \\
\text { Em seguida, começaram a explicar os efeitos da testosterona e dos hormônios } \\
\text { sintéticos. Logo em seguida, os alunos manifestaram o entendimento do porquê do }\end{array}$ \\
\hline
\end{tabular}




\begin{tabular}{|c|c|}
\hline & $\begin{array}{l}\text { crescimento do clitóris da mulher relatada no texto. Nesse momento, os alunos } \\
\text { conseguiram articular as relações entre clitóris, androginia, heteroginia, } \\
\text { transexualidade e hermafroditismo. } \\
\text { Os alunos, após a apresentação de um dos trabalhos sobre exercícios físicos, } \\
\text { compreenderam que o ganho muscular é uma soma de alimentação, sono, exercícios, } \\
\text { bem estar. }\end{array}$ \\
\hline Prática social & $\begin{array}{l}\text { Após os trabalhos um aluno quis saber se o tratamento diferente da mulher tinha } \\
\text { haver com machismo. } \\
\text { Quanto ao trabalho sobre transexualidade, a aluna Rafaela disse que acreditava que } \\
\text { existem casos em que seria justificada a cirurgia plástica, para mudança de sexo. } \\
\text { Quando viram o trabalho sobre raças, um aluno chamado Arthur se destacou: vocês } \\
\text { disseram que não existe uma raça mais inteligente que outras então eu não concordo } \\
\text { com as cotas, pois todos têm as mesmas condições de ficar com a vaga. Muitos } \\
\text { concordaram com Arthur. } \\
\text { O aluno direcionou seu pensamento a partir de uma premissa de caráter geral (o fato } \\
\text { de, biologicamente, não haver diferença significativa na inteligência das diferentes } \\
\text { raças), passando pelo caso particular das políticas de cotas nas universidades públicas } \\
\text { até a emissão de um juízo acerca do estabelecimento da política de cotas. } \\
\text { O que influencia as pessoas a consumirem os esteroides? O aluno Oséas disse que era } \\
\text { para conseguir uma namorada. Ao realizar mais questionamentos, concluímos que } \\
\text { são pessoas que possuem baixa autoestima, outro aluno completou que o "padrão de } \\
\text { beleza" faz com que as pessoas tomem atitudes idiotas. }\end{array}$ \\
\hline
\end{tabular}

Fonte: Relatos registrados no Diário de Bordo.

Para a discussão dos dados, elegemos duas das várias categorias apresentadas na grelha, pois julgamos das mais relevantes no processo de alfabetização científica, da perspectiva da práxis, quais sejam, raciocínio lógico e pratica social a partir de uma visão crítica, construída no decorrer da prática pedagógica.

\subsection{Raciocínio lógico}

Freire (1998) nos alerta sobre a antidialogicidade provocada pela educação bancária, cujos efeitos podem ser negativos. A concepção bancária de educação expõe suas raízes na pedagogia tradicional, que se constitui, entre outros predicados, pelo cerceamento do pensamento livre dos discentes, em outras palavras, restringe a capacidade criativa e reprime o raciocínio lógico. Assim, 
o suporte epistemológico desta pesquisa compreende apropriação de teorias pedagógicas fundadas na educação libertadora, de modo a proporcionar o despertar do raciocínio lógico dos discentes. Os debates provocaram nos alunos reflexões teóricas baseadas em sua participação nos momentos de efervescência teórica, conforme indicado nos exemplos do Quadro 3.

\subsection{Visão crítica da cultura corporal na prática social}

Desde a promulgação da Lei de Diretrizes e Bases da Educação Nacional que o pensamento crítico, ora presente apenas na educação superior, está formalmente incorporado à educação básica, cabendo à educação superior, após a vigência da referida lei, o foco no pensamento reflexivo. Buscamos destacar os momentos que demostraram a apropriação crítica das manifestações da cultura corporal que, por muitas vezes, são deixados à margem das matrizes curriculares. Como nossa proposta foi de ampliação do conceito de cultura corporal exposto pelo Coletivo de autores (1992), recortamos os momentos que evidenciam a presença destes conteúdos tratados sob o viés libertador proposto por Paulo Freire. Quando por exemplo os alunos visualizaram o anuncio do Boticário ("Aqui a vida é linda"), eles conseguiram perceber que no comercial o mundo parecia perfeito, porque mostrava as pessoas sempre belas e felizes, e que fora do comercial, a vida era feia. Quando questionamos, já quase no final da mostra, se os alunos conseguiam identificar algum tipo de imposição de um padrão universal de beleza, rapidamente eles conseguiram articular o padrão de beleza aos modelos das grandes corporações Victoria's Secret, O Boticário, Monange, Dove, entre outras.

A contestação de padrões de cultura corporal estabelecido pela cultura de massa era um dos objetivos que pretendíamos alcançar com a sequência didática e com a mostra cultural. Neste caso, a libertação proposta por Freire (1998) aconteceu quando os alunos perceberam que seus desejos são manipulados pela indústria da beleza. O consumo compulsivo de produtos relacionados à composição da imagética corporal foi desvelado durante as discussões sobre a influência da indústria da moda na gênese dos nossos desejos. A Pedagogia Libertadora se inclui nas teorias pedagógicas progressistas, as quais partem de uma leitura crítica da realidade social e defendem a educação como um instrumento de transformação social e política da classe trabalhadora. A Pedagogia Libertadora e as teorias pedagógicas progressistas possuem seu berço na concepção histórico-social do homem (ARANHA, 2006). 
Em nosso estudo, procuramos integrar os pressupostos da teoria da complexidade por meio do trato interdisciplinar dos conteúdos. Esta ação possibilitou a vivência dos postulados da educação científica defendidos neste trabalho em momentos interdisciplinares que favoreciam uma leitura à luz dos princípios da teoria de Edgar Morin. A mostra cultural se constituiu como o ponto alto da nossa ação para desenvolvimento da educação científica. Um evento deste gênero é defendido por teóricos da área de divulgação científica (VOGT, 2011) que dão o suporte necessário para a proposta de socialização da ciência. A mostra cultural permitiu a exploração conjunta de vários temas da divulgação científica, possibilitando criar um ambiente favorável para a compreensão mais ampla e interdisciplinar da cultura corporal pelos atores escolares.

O Quadro 3 que anteriormente apresentamos, de modo a subsidiar a compreensão do processo de alfabetização científica, observado durante a mostra cultural, como consequência da Sequência Didática "Gente e corpo", buscou destacar alguns episódios ocorridos em campo, os quais foram coletados em diário de campo, reveladores da manifestação do processo de alfabetização científica. Trata-se de indicadores que buscaram revelar

\begin{abstract}
"competências próprias das ciências e do fazer científico: competências comuns desenvolvidas e utilizadas para a resolução, discussão e divulgação de problemas em quaisquer das Ciências quando se dá a busca por relações entre o que se vê do problema investigado e as construções mentais que levem ao entendimento (SASSERON; CARVALHO, 2008, p. 338).
\end{abstract}

Assim, legitimamos teoricamente a apreciação didática dos episódios selecionados nos indicadores da alfabetização científica sugeridos por Sasseron e Carvalho (2008), conforme já ficou dito, adaptados por Leonor (2013) os quais foram utilizados para indicar algumas ações e habilidades produzidas para resolução de um problema.

A Divulgação Científica contribuiu de várias maneiras. As feiras de ciências e as mostras culturais realizadas em escolas, com a organização de professores e alunos, apresentam trabalhos orientados por professores, os quais, ainda que com fundamentos científicos simples, revelam a ação educativa voltada para a educação científica. Isso contribui para a interação entre os visitantes e expositores, além de contribuir para a formação do aluno. As feiras de ciências e mostras culturais podem popularizar o conhecimento científico, revelar novos talentos a partir da elaboração de trabalhos, ampliar a articulação entre escola e comunidade e despertar o espírito cientifico. Nossa mostra cultural teve como objetivo servir de espaço para divulgar a ciência para 
os atores escolares, e evidenciar como a divulgação científica acontece nas escolas, além de revelar seu potencial no campo a alfabetização científica e para favorecer o trabalho colaborativo entre os docentes.

Para finalizar, apresentamos a percepção dos professores quanto ao desenvolvimento da sequência didática e à realização da mostra cultural. $O$ instrumento de coleta era composto de cinco questões, sendo quatro abertas e uma fechada. A questão fechada tinha cinco categorias, às quais o professor deveria avaliar o potencial educativo da mostra cultural, em uma escala de 1 a 5. Tendo em vista que este instrumento buscava dar conta da percepção dos professores, procuramos apresentar as respostas agrupadas, seguidas de breve discussão. Dos cinco professores que validaram a sequência didática, somente três se dispuseram a responder aos instrumentos, os quais foram enviados por email e depois recolhidos por nós, no final do mês de setembro de 2015.

Quando perguntados se sabiam o que era divulgação científica e se já utilizaram textos de divulgação científica em suas práticas pedagógicas, a pedagoga respondeu não para as duas perguntas e os dois professores disseram que já utilizaram tais gêneros, porque em cursos de capacitação, a secretaria de educação do estado costuma incentivar seu uso por meio das revistas disponíveis na biblioteca das escolas, tais como Ciência Hoje das crianças. O desconhecimento da pedagoga pode ser um complicador para o planejamento da ação docente.

Quando questionados se já haviam participado de uma ação interdisciplinar e qual a importância de terem participado da sequência didática relacionada ao corpo e mídia, a resposta foi unânime em revelar que todos participaram de ações pedagógicas interdisciplinares e consideram muito significativo trazer este tema para sala de aula e levar à exposição o tema corpo e mídia. Tendo em vista os constantes ataques de grupos radicais islâmicos, atividades assim ajudam a desconstruir as representações sociais negativas acerca de tais culturas.

Quando perguntados sobre a relevância do trabalho colaborativo, os três professores revelaram saber do que se tratava e identificaram que o trabalho colaborativo ocorreu no transcurso da mostra cultural. No que diz respeito ao trabalho colaborativo, vale destacar o papel da realização da mostra cultural como ensejadora das apropriações mútuas entre os docentes, onde os limites dos conhecimentos de ciências da natureza se misturaram com os conhecimentos de 
humanidades, de forma dinâmica e dialógica. A aprendizagem colaborativa entre docentes configurou-se como uma potencialidade criando uma alternativa educativa, no caso a realização da mostra, para auferir o sucesso na tarefa pedagógica (DAMIANI, 2008).

Ao serem solicitados a avaliar a realização da mostra cultural, a tabela continha cinco quesitos. 0 primeiro buscava avaliar o potencial integrador da mostra cultural. Para este item, todos os professores atribuíram nota cinco, o que denuncia uma forma positiva de avaliar ações pedagógicas de natureza colaborativa. Quanto ao fato de a feira se configurar como um espaço de socialização da ciência, dois professores atribuíram nota cinco e um professor nota quatro. Essa nota talvez se explique por desconhecimento do potencial da mostra cultural em socializar a ciência.

Quanto ao papel da feira na formação de criticidade e de alfabetização científica, dois professores atribuíram nota quatro e um nota cinco. Talvez por nunca terem realizado uma mostra, alguns professores não creditam tal potencial à mostra. As mostras culturais, os clubes de ciências, as feiras podem se configurar como espaços para o desenvolvimento de atitudes e do senso crítico com relação à ciência, na medida em que favorecem condições para os atores escolares discutirem, e refletirem, sobre aspectos científicos, éticos e morais na utilização da ciência e das tecnologias. Eventos assim permitem que os estudantes utilizem tais conhecimentos na vida diária, compreendendo e intervindo socialmente em situações que impactam suas vidas (MENEZES; SCHROEDER; SILVA, 2012).

No item que buscava avaliar o potencial da mostra para desenvolvimento de sociabilidades, houve unanimidade na atribuição de nota cinco, isso porque demanda, para sua realização, o trabalho colaborativo e a troca de fazeres e de habilidades, na ação pedagógica. No último item, que buscava avaliar o potencial da mostra e ensejar o trabalho colaborativo os três professores atribuíram nota quatro porque consideraram que mais professores poderiam ter contribuído. É significativa esta avalição porque transparece que eles avaliaram a participação da equipe e não o potencial da mostra, em si, em ensejar um trabalho colaborativo.

A última questão buscava uma avaliação geral, e houve unanimidade na afirmação de que mostras culturais deveriam ser realizadas com mais frequência e com ampla divulgação na escola toda, concitando a comunidade escolar para sua participação e não somente as duas turmas. 
O ensino de Ciências precisa conduzir os alunos para a apropriação dos conhecimentos científicos, a partir do desenvolvimento de propostas metodológicas que favoreçam a construção crítica e criativa desse mesmo conhecimento. As escolas devem se transformar em espaço privilegiado para interlocuções entre as diversas dimensões dos campos de conhecimentos e dos saberes humanos, permitindo surgir espaços de trabalho colaborativo. Em face do desafio de realizar as mostras culturais com mais frequência, como locus para a alfabetização científica, defendemos a importância de tais ações para a dinamização da educação científica com vistas à criação da cultura cientifica dos estudantes do ensino fundamental. Somente a partir daí, a alfabetização científica poderá contribuir para a formação de sujeitos mais participativos, com habilidade de fazerem escolhas mais conscientes para si e para sua comunidade.

\section{CONSIDERAÇÕES FINAIS}

A proposta deste trabalho foi desenvolver uma sequência didática interdisciplinar que conduzisse a um conhecimento frequentemente negligenciado pelos currículos escolares em relação à cultura corporal e ao final organizar uma mostra cultural como evento de divulgação científica, a qual serviu de fio condutor das discussões.

A abordagem da cultura corporal direcionada aos pressupostos da educação científica constituiuse um grande desafio, caracterizado pela escassez de propostas que apontem para um olhar mais científico da cultura corporal, uma vez que a literatura expressiva da área propõe um olhar mais voltado à prática pedagógica (BRACHT, 2003; COLETIVO DE AUTORES, 1992). Neste estudo, constatamos que a exploração científica da cultura corporal ainda é um terreno pouco trilhado.

No percurso do desenvolvimento da prática pedagógica, convidamos os discentes a penetrar no universo da cultura corporal desvelando suas nuances, incorporando novos elementos aos seus conhecimentos prévios e, a partir daí, enxergarem seu corpo inserido no contexto de uma sociedade de consumo. A proposta era destacar que existe uma força que conduz os oprimidos a se tornarem novos opressores quando eventualmente ascendem dentro de seu grupo. De certo modo, um adolescente que sempre se sentiu oprimido em relação ao seu corpo que destoa dos padrões estéticos ditados, quando colocado em face do chamado corpo ideal, modelado pela sociedade de consumo, ao conseguir se colocar dentro deste padrão socialmente estabelecido, passará a ser mais um propagador da ideologia do corpo ideal. 
A divulgação científica, que já era objeto de discussões em decorrência do potencial educativo que possui, se mostrou conveniente como fio condutor das discussões sobre a cultura corporal. Hodiernamente, a disponibilidade de informações, especialmente no meio digital, nos oferece um imenso acervo de materiais que podem ser usados no meio escolar. No caso da cultura corporal, também são vastos os materiais disponibilizados em diversos gêneros, revistas, colunas de jornais, documentários, entrevistas com cientistas, entre outros, viabilizando qualquer iniciativa de usar a divulgação científica para enriquecer a abordagem dos assuntos relacionados à cultura corporal.

\section{REFERÊNCIAS}

ANDRE, M. E. D. A. Etnografia da prática escolar. 18. ed. Campinas: Papirus, 2013.

ANDRÉ, M. E. D. A.\& Ludke, M. Pesquisa em educação: abordagens qualitativas. 2. ed. Rio de Janeiro: E.P.U, 2013.

ARANHA, M. L. A. Filosofia da educação. São Paulo: Moderna, 2006.

AULER, D. Novos caminhos para a educação CTS: ampliando a participação. SANTOS, W. L. P.; AULER, D. (Eds.) (2011). CTS e Educação Científica:desafios, tendências e resultados de pesquisas. Brasília: Editora Universidade de Brasília, 2011 p. 459.

BARDIN, L. Análise de conteúdo. Ed. Revista e ampliada São Paulo: Edições 70, 2011.

BRACHT, V. Educação Física e ciência: cenas de um casamento (in)feliz. 2. ed. ljuí: Unijuí, 2003.

CECCARELLIi, P. R. Uma breve história do corpo. In: LANGE, E. S. N.\& TARDIVO, L. C. (Eds.). Corpo, alteridade e sintoma: diversidade e compreensão. São Paulo: Vetor, 2011 p. 01 -15.

CHASSOT, A. Alfabetização científica: uma possibilidade para a inclusão social. Revista Brasileira de Educação, 22, 2003 p. $89-100$

COLETIVO DE AUTORES. Metodologia do ensino da Educação Física. São Paulo: Cortez, 1992.

DAMIANI, M.F. Entendendo o trabalho colaborativo em educação e revelando seus benefícios. Educar, Curitiba, UFPR, n. 31, pp. 213-230, 2008. Disponível em: <http://www.scielo.br/pdf/er/n31/n31a13>. Acesso em: 25 nov. 2015.

DELIZOICOV, D.; ANGOTTI, J. A. \& PERNAMBUCO, M. M. Ensino de ciências: Fundamentos e métodos. São Paulo: Cortez, 2007.

DEMO, P.Educação e alfabetização científica. Campinas: Papirus, 2010.

FREIRE, P. Pedagogia do oprimido. 25. ed. Rio de Janeiro: Paz e Terra, 1998.

GEERTZ, C. A interpretação das culturas. Rio de Janeiro: Guanabara Koogan, 1989.

GIL, A. C. Como elaborar projetos de pesquisa. 3. ed. São Paulo: Atlas, 1996.

GUIMARÃES, Y. A. F.; GIORDAN, M. Instrumento para construção e validação de sequências didáticas em um curso a distância de formação continuada de professores. Anais... VIII Encontro Nacional de Pesquisa em Educação em Ciências, Campinas, 2011. 
LEONOR, P. B. Ensino por investigação nos anos iniciais: análise de sequências didáticas de ciências sobre seres vivos na perspectiva da alfabetização científica. Dissertação (Mestrado em Educação em Ciências e Matemática) - Programa EDUCIMAT do IFES, Vitória, 2013.

LORENZETTI, L.; DELIZOICOV, D. Alfabetização científica no contexto das séries iniciais. Ensaio. Pesquisa em Educação e ciências. v. 3 n. 1 - Jun. p. $1-16, \quad 2001 . \quad$ Disponível em: <http://disciplinas.stoa.usp.br/pluginfile.php/165076/mod_resource/content/1/Lorenzetti\%20e\%20Delizoicov\%20\%2 82001\%29\%20Alfabetiza\%C3\%A7\%C3\%A3o\%20cient\%C3\%ADfica\%20no\%20contexto\%20das\%20s\%C3\%A9ries\%20inic iais.pdf>. Acesso em: 25 nov. 2015.

MENEZES, C.; SCHROEDER, E; SILVA, V. Clubes de ciências como espaço de alfabetização científica e ecoformação. Atos de pesquisa em Educação, v. 7, n. 3, p. 811-833, set./dez, 2012.

MORIN, E. Introdução ao pensamento complexo. 4. ed. Porto Alegre: Sulina, 2011.

SASSERON, L. H.; CARVALHO, A. M. P. Alfabetização científica: uma revisão bibliográfica. Investigações em Ensino de
Ciências,
v.16
(1),
p. 59-77,
2011.
Disponível
em:

<http://www.if.ufrgs.br/ienci/artigos/Artigo_ID254/v16_n1_a2011.pdf>. Acesso em: 23 nov, 2015.

SILVA, G. A.; AROUCA, M. C.; GUIMARAES, V. F. Exposições de divulgação da ciência. In: MASSARANI, L.; MOREIRA, I. DE C.; BRITO, F. (Eds.). Ciéncia e Público. Rio de Janeiro: Casa da Ciência/UFRJ, 2002 p. 231.

SILVA, H. C. O que é divulgação científica? Ciência \& Ensino, v. 1, n. 1, p. 53-59, 2006. Disponível em: <http://prc.ifsp.edu.br/ojs/index.php/cienciaeensino/article/view/39/0>. Acesso em: 20 set. 2015.

TEIXEIRA COELHO, J. O que é ação cultural. São Paulo: Brasiliense, 2001.

VOGT, C. De ciências, divulgação, futebol e bem-estar cultural. In: Porto, C. M.; Brotas, A. M. P.; Bortoliero, S. T. (Eds.). Diálogos entre ciência e educação científica. Salvador: EDUFBA, 2011 p. 7-17. 